\title{
Effect of chronic exposure to inorganic arsenic on intestinal cells
}

Chiocchetti, G.M., Vélez, D., Devesa, V*.

Instituto de Agroquímica y Tecnología de Alimentos (IATA-CSIC), Calle Agustín Escardino 7, 46980 - Paterna (Valencia), Spain.

*To whom correspondence should be addressed (telephone (+34) 963900 022; fax (+34) 963636 301; e-mail: vdevesa@iata.csic.es)

Running title: Effect of chronic exposure to inorganic arsenic on intestinal cells 


\begin{abstract}
Chronic exposure to inorganic As $[\mathrm{As}(\mathrm{III})+\mathrm{As}(\mathrm{V})]$ is associated with type-2 diabetes, vascular diseases, and various types of cancer. Although the oral route is the main way of exposure to inorganic As, the adverse gastrointestinal effects produced by chronic exposure are not well documented.
\end{abstract}

The aim of the present study is to evaluate the effect of chronic exposure to As(III) on the intestinal epithelium. For this purpose, NCM460 cells, non-transformed epithelial cells from the human colon, were exposed to As(III) $(0.01-0.2 \mathrm{mg} / \mathrm{L})$ for 6 months and monitored for acquisition of a tumor-like phenotype. Secretion of matrix metalloproteinases (MMPs), histone modifications (H3 acetylation), hyperproliferation capacity, formation of floating spheres, anchorage-independent growth, release of cytokine IL-8, and expression of relevant genes in colon tumorigenesis were assessed.

The results show a maintained pro-inflammatory response from the beginning, with an increase in IL-8 secretion $(\leq 570 \%)$. Down-regulation of $C D X 1$ and $C D X 2$ was also observed. After 14 weeks of exposure, cells presented marked increases in MMP-2 secretion and histone modifications. As(III)-treated cells were hyperproliferative, grew in low-serum media and were able to form free-floating spheres. Overall, these data suggest that exposure of human colon epithelial cells to As(III) facilitates acquisition of transformed cell characteristics.

Short Abstract: Chronic exposure to environmental relevant concentrations of As(III) facilitates acquisition of transformed cell characteristics in intestinal cells (marked increases in MMP-2 secretion, histone modifications, down-regulation of $C D X 1$ and $C D X 2$, anchorage-independent growth, and free-floating spheres formation, among 
others). The increase in cellular transformation characters is accompanied by a proinflammatory process that begins in the first weeks of exposure and that could be partly responsible for it.

Keywords: inorganic arsenic; arsenite; intestinal epithelium; cellular transformation; inflammation 


\section{Introduction}

Inorganic arsenic (As) $[\mathrm{As}(\mathrm{III})+\mathrm{As}(\mathrm{V})]$ is considered carcinogenic for humans by the International Agency for Research on Cancer (IARC, 2004). It is currently estimated that about 200 million people are chronically exposed to inorganic As through drinking water (WHO, 2012). Although skin cancers are the most frequent, strong epidemiological associations also exist between As ingestion and bladder, lung, and perhaps kidney and liver cancers (Rossman, 2003). The increase in cancer risk observed in epidemiological studies is attributed mainly to the presence of trivalent inorganic As (Rossman, 2003); however, it seems that metabolites, especially the trivalent monomethylated form [MMA(III)], also play an important role in this process.

The toxic effects of inorganic As on target organs have been studied extensively, but there is little information about the toxicity of this form of arsenic in the gastrointestinal tract, although food and drinking water are the main pathway for exposure to this toxic element for most of the population. In vitro studies have shown that acute exposure to inorganic As, especially the trivalent form and the trivalent metabolites derived from it, generates oxidative stress and a pro-inflammatory response, and also a redistribution of the proteins that form tight junctions, which are responsible for maintaining the structure of the intestinal epithelium (Calatayud et al., 2013, 2014). Subchronic exposure also produces a prolonged pro-inflammatory response, which may be the cause of the loss of barrier function of intestinal monolayers and the dysregulation of the cell renewal process observed in intestinal cells subchronically exposed to As(III) (Chiocchetti et al., 2018). Numerous studies show that inflammation continuing in time and loss of barrier function may favor the establishment of chronic inflammatory pathologies in the intestine, and may increase the incidence of carcinogenic processes (Rubin et al., 2012). In this context, a study carried out in Taiwan demonstrated a greater prevalence of colon cancer 
[standardized mortality ratio, SMR: 117-203 (males); 126-210 (females)] in a population exposed to high concentrations of As in drinking water $(0.35-1.14 \mathrm{mg} / \mathrm{L})(\mathrm{Chen}$ et al., 1985).

The ability of As(III) to induce transformations in various types of human cells has been studied in vitro (Chen and Costa, 2017), but there is no research on intestinal cells. Studies indicate that As carcinogenesis might result from oxidative stress, altered growth factors, chromosomal abnormality, immune dysregulation, and aberrant epigenetic regulations (Lee et al., 2010). The aim of the present study is to determine whether chronic exposure to As(III) favors the appearance of characteristics typical of transformed cells in intestinal epithelial cells.

\section{Material and methods}

\subsection{Reagents}

The As(III) standard (1000 mg/L) was prepared by dissolving $1.320 \mathrm{~g}$ of $\mathrm{As}_{2} \mathrm{O}_{3}$ (Riedel de Haën, Seelze, Germany) in $25 \mathrm{~mL}$ of $\mathrm{KOH}$ at $20 \%$ (m/v), neutralizing with $20 \% \mathrm{H}_{2} \mathrm{SO}_{4}$ $(\mathrm{v} / \mathrm{v})$, and making up to a final volume of 1 liter with $1 \% \mathrm{H}_{2} \mathrm{SO}_{4}(\mathrm{v} / \mathrm{v})$. The standards with lower concentrations were prepared daily from the intermediate standards.

All the reagents for cell maintenance were acquired from HyClone (Fisher Scientific, Madrid, Spain) [Dulbecco's Modified Eagle Medium (DMEM) with high glucose (4.5 $\mathrm{g} / \mathrm{L}$ ), fetal bovine serum (FBS), penicillin and streptomycin solution, amphotericin B, sodium pyruvate and trypsin $(0.5 \mathrm{~g} / \mathrm{L}) /$ EDTA (ethylenediaminetetraacetic acid, $0.2 \mathrm{~g} / \mathrm{L}$ ) solution].

For the evaluation of the toxicological endpoints the following reagents were used: ELISA Human IL-8/CXCL8 kit (Sigma, Madrid, Spain); bovine serum albumin (BSA, Biowest, Labclinic, Barcelona, Spain); anti-Histone H3 (acetyl K9 + K14 + K18 + K23 
+ K27) antibody (ab47915, Abcam, Cambridge, UK), Hybond-P PVDF membrane (GE Healthcare, Barcelona, Spain); Bio-Rad Protein Assay (Bio-Rad, Madrid, Spain); NucleoSpin RNA II kit (Macherey-Nagel, Cultek, Valencia, Spain); Reverse Transcriptase Core Kit (Eurogentec Headquarters, Cultek); LightCycler ${ }^{\circledR} 480$ SYBR Green I Master Mix (2X, Roche, Madrid, Spain); primers (Biolegio, Teknokroma, Barcelona, Spain); human recombinant proteins MMP-9 (Life Technologies; Fisher) and MMP-2 (Abcam); trypan blue staining (0.4\%), crystal violet and Coomassie brilliant blue R-250 (Sigma); DMEM F-12 medium and B-27 supplement (Gibco, Fisher Scientific); epidermal growth factor and basic fibroblast growth factor (Immuno Tools, Friesoythe, Germany); insulin (Sigma).

\subsection{Cell line culture conditions and treatment}

The non-transformed human colon mucosal epithelial cell line NCM460 (Moyer et al., 1996) was acquired from INCELL Corporation (San Antonio, TX, USA). For the treatments, cells were seeded at a density of $4 \times 10^{4}$ cells $/ \mathrm{cm}^{2}$ in $25 \mathrm{~cm}^{2}$ flasks, and from the beginning they were exposed to solutions of $\mathrm{As}(\mathrm{III})(0.01,0.05,0.1$, and $0.2 \mathrm{mg} / \mathrm{L})$ prepared in DMEM at $\mathrm{pH} 7.4$. The medium was supplemented with $7.5 \%$ (v/v) FBS, 100 $\mathrm{U} / \mathrm{mL}$ of penicillin, $0.1 \mathrm{mg} / \mathrm{mL}$ of streptomycin, $0.0025 \mathrm{mg} / \mathrm{mL}$ of amphotericin $\mathrm{B}$, and 1 $\mathrm{mM}$ of sodium pyruvate. The cells were incubated at $37{ }^{\circ} \mathrm{C}$ in an atmosphere with $95 \%$ relative humidity and a $\mathrm{CO}_{2}$ flow of $5 \%$, and the medium was changed every 2 days. When the cell monolayer reached $80 \%$ confluence, the cells were detached with a solution of trypsin and EDTA, and they were reseeded in a $25 \mathrm{~cm}^{2}$ flask in the same culture conditions. The treatment time was 24 weeks. Cells not treated with As were also grown (matched controls). 


\subsection{Determination of cytokine levels}

From the fourth week onward, the conditioned media for each treatment were recovered during subculturing for analysis of the pro-inflammatory cytokine IL-8 by means of a specific ELISA kit, following the manufacturer's instructions. The results were normalized per number of cells determined by trypan blue staining.

\subsection{Histone modification}

From the sixth week onward, $1 \times 10^{6}$ cells from each of the treatments were recovered during subculturing for analysis. Histones were extracted according to the protocol described by Shechter et al. (2007). The total amount of protein in the extract was determined by the Bradford method using the Bio-Rad Protein Assay kit.

Twenty $\mu \mathrm{g}$ of protein was subjected to electrophoresis in $12 \%$ SDS-polyacrylamide gel, and was transferred to a Hybond-P PVDF membrane by electroelution for $1 \mathrm{~h}$. After transfer, the membranes were blocked with $5 \%(\mathrm{~m} / \mathrm{v})$ of BSA in TBS buffer for $1 \mathrm{~h}$. The membranes were then incubated overnight at $4{ }^{\circ} \mathrm{C}$ with the corresponding primary antibody diluted 1:2000 in blocking solution. Then they were incubated for $1 \mathrm{~h}$ with the secondary antibody (goat anti-rabbit $\operatorname{IgG}$ ) diluted 1:10000 in blocking solution. The bands obtained were detected with the ECL ${ }^{\mathrm{TM}}$ Advance Western Blot system (GE Healthcare). Densitometric analysis of the bands was performed with the ImageJ program.

\subsection{Gene expression}

Gene expression of the homeobox genes $C D X 1$ and $C D X 2$ and the $C D 133$ (PROM1) gene was evaluated. From the third week onward, $1 \times 10^{6}$ cells from each treatment were isolated during subculturing for extraction of total RNA. The RNA obtained was spectroscopically quantified in a Nanodrop ND-1000 (NanoDrop Technologies, 
Wilmington, NC, USA). First-strand complementary DNA (cDNA) was obtained from 200 ng of total RNA.

qPCR was performed using the LightCycler ${ }^{\circledR} 480$ Real-Time PCR Instrument (Roche

Diagnostics). Reactions were carried out in a $10 \mu \mathrm{L}$ final volume containing $5 \mu \mathrm{L}$ of LightCycler $^{\circledR} 480$ SYBR Green I Master Mix, $2.5 \mu \mathrm{L}$ of cDNA $(20 \mathrm{ng} / \mu \mathrm{L}), 1 \mu \mathrm{L}$ of each forward and reverse primer $(10 \mu \mathrm{M})$, and nuclease-free water. No-template controls were run to verify the absence of genomic DNA. The oligonucleotide sequences used are shown in Table 1. PCR efficiency curves for each gene were calculated using 5 duplicate 5-fold dilutions of cDNA.

The qPCR conditions were $95{ }^{\circ} \mathrm{C}$ for $5 \mathrm{~min}$, followed by 40 cycles: $10 \mathrm{~s}$ denaturation at $95{ }^{\circ} \mathrm{C}, 10 \mathrm{~s}$ annealing at $55^{\circ} \mathrm{C}$, and $20 \mathrm{~s}$ elongation at $72{ }^{\circ} \mathrm{C}$. The melting curve of each sample was analyzed after each PCR run to confirm PCR product specificity. Data were analyzed with the Relative Expression Software Tool (REST 2009).

\subsection{Cell proliferation in serum-depleted medium}

This assay was performed with cells isolated during subculturing the weeks 6,10 , and 18 of the treatment. Cell proliferation was determined by plating $2.6 \times 10^{5} \mathrm{cells} / \mathrm{cm}^{2}$ in 12 well plates in DMEM medium with reduced serum concentrations (1\%). The cells were incubated at $37{ }^{\circ} \mathrm{C}$ in an atmosphere with $95 \%$ relative humidity and a $\mathrm{CO}_{2}$ flow of $5 \%$ for a period of 7 days. Cell number was assessed by direct cell counting after staining with trypan blue.

\subsection{Secreted matrix metalloproteinase (MMP-2 and MMP-9) activity}

Cells chronically exposed for 24 weeks were isolated during subculturing and seeded in 12-well plates at a density of $2.6 \times 10^{5} \mathrm{cells} / \mathrm{cm}^{2}$ in DMEM without supplementation. 
After $48 \mathrm{~h}$ the medium was recovered and centrifuged at $1400 \mathrm{rpm}$ for $5 \mathrm{~min}$. The protein fraction was concentrated approximately 50 times using Amicon Ultra-2 30K tubes (Millipore, Fisher Scientific), following the manufacturer's instructions.

The gelatinolytic activity of MMP-2 and MMP-9 in the conditioned medium was assayed by a standard zymographic method with reagents from Bio-Rad, following the manufacturer's instructions. Briefly, samples were resolved in $10 \%$ precast gels with gelatin by SDS-PAGE at $100 \mathrm{~V}$ for $60 \mathrm{~min}$ and then incubated in $1 \mathrm{x}$ zymogram renaturing buffer for $30 \mathrm{~min}$. Afterwards, the gels were incubated overnight with 1x zymogramdeveloping buffer at $37^{\circ} \mathrm{C}$. After reaction, the gels were stained with Coomassie brilliant blue R-250 in 10\% acetic acid solution for $3 \mathrm{~h}$ and distained for $30 \mathrm{~min}$ in a solution of methanol (20\%) and acetic acid (10\%). White lysis zones indicating gelatin degradation were revealed, and the areas were measured densitometrically with the ImageJ program. Human recombinant proteins MMP-9 and MMP-2 were used as positive controls.

\subsection{Anchorage-independent growth}

Anchorage-independent growth was determined using the soft agar colony assay. A solution of $0.5 \%$ agar-containing medium [DMEM supplemented with $10 \%(\mathrm{v} / \mathrm{v}) \mathrm{FBS}$, $100 \mathrm{U} / \mathrm{mL}$ of penicillin, $0.1 \mathrm{mg} / \mathrm{mL}$ of streptomycin, and $0.0025 \mathrm{mg} / \mathrm{L}$ of amphotericin B] was layered in each well of a 6-well plate $(1.5 \mathrm{~mL})$, and allowed to solidify for $30 \mathrm{~min}$. A suspension containing $1 \times 10^{4}$ cells obtained from the week 24 in supplemented DMEM was mixed with $0.7 \%$ agar medium, giving a $0.35 \%$ agar solution. The suspension $(1.5$ $\mathrm{mL}$ ) was layered on top of the $0.5 \%$ bottom layer of agar. The cells were incubated at 37 ${ }^{\circ} \mathrm{C}$, with the addition of $0.5 \mathrm{~mL}$ of supplemented DMEM twice a week to avoid dehydration of the agar. After 21 days the colonies were stained with crystal violet at $0.01 \%$ in PBS. Colonies measuring $\geq 0.2 \mathrm{~mm}$ were counted. 


\subsection{Free-floating sphere formation}

In order to obtain floating spheres, cells were grown in serum-free medium, in nonadherent conditions, following the protocol described by Johnson et al. (2013). The cells isolated during subculturing in weeks 18 and 24 were seeded $\left(1.5 \times 10^{4}\right.$ cells $\left./ \mathrm{mL}\right)$ in ultralow-attachment 96-well plates (Corning, Cultek), in DMEM F-12 medium supplemented with $20 \mathrm{ng} / \mathrm{mL}$ of epidermal growth factor, $10 \mathrm{ng} / \mathrm{mL}$ of basic fibroblast growth factor, 5 $\mu \mathrm{g} / \mathrm{mL}$ of insulin, $0.4 \% \mathrm{BSA}$ and B-27 supplement. After incubation for one week (37 $\left.{ }^{\circ} \mathrm{C}\right)$, tumorsphere size and number were evaluated under a phase-contrast microscope.

\subsection{Statistical analysis}

The results were statistically analyzed by one-factor analysis of variance (ANOVA) with Tukey's or Fisher HSD post hoc multiple comparison or using the Student t-test (SigmaPlot version 13.0). Differences were considered significant for $\mathrm{p}<0.05$.

\section{Results}

3.1. Release of the proinflammatory cytokine $I L-8$. Several inflammatory interleukins (IL1, IL-6, IL-8, and IL-18) have been linked with tumorigenesis, suggesting that inflammation is associated with cancer development (Aggarwal et al., 2006). In this study, release of the interleukin IL-8 by the NCM460 cells chronically exposed to As(III) was measured (Figure 1). An increase in IL-8 release at the highest concentrations of $\operatorname{As}(\mathrm{III})(0.1$ and $0.2 \mathrm{mg} / \mathrm{L})$ was observed from week 4 (the first measurement made). This effect was maintained during the remainder of the 24 weeks of exposure (2.1-4.9-fold changes with respect to the matched control cells). Exposure of NCM460 cells to 0.05 $\mathrm{mg} / \mathrm{L}$ of As(III) increased IL-8 release from weeks 20 to 24 (2.9-4.0-fold changes with respect to the matched control cells). 
3.2. Histone modification. The changes in the patterns of acetylation and methylation of histones are known to be an epigenetic mechanism involved in the tumorogenesis of inorganic As (Roy et al., 2015). Figure 2 shows the H3 acetylation in NCM460 cells chronically exposed to $\mathrm{As}(\mathrm{III})(0.01,0.05,0.1$, and $0.2 \mathrm{mg} / \mathrm{L})$ for 12,18 , and 20 weeks. Chronic exposure to As(III) increased the level of modified histone H3 in week 20 (3.23.7-fold changes), whereas no significant changes were observed in previous weeks.

3.3. Gene expression. Table 2 shows the expression of $C D X 1, C D X 2$ and $C D 133$ in NCM460 cells chronically exposed to As(III) $(0.01,0.05,0.1$, and $0.2 \mathrm{mg} / \mathrm{L})$ for 3,13 , and 19 weeks with respect to the matched control cells. CDX genes, whose expression decreases in tumorigenic cells (Werling et al., 2003; Wong et al., 2004), showed a general decrease in their expression (3.6-103-fold changes). The down-regulation was observed from the third week of exposure and it was maintained throughout the rest of the experiment.

CD133 is overexpressed in colorectal cancer cells (Ricci-Vitiani et al., 2007) and has been identified as a possible marker for colorectal cancer (Ren et al., 2013). Its expression increased in all the As(III) treatments, except for $0.2 \mathrm{mg} / \mathrm{L}$, in week 13 (6.2-11.8-fold changes).

3.4. Cell proliferation in serum-depleted medium. Figure 3 shows the proliferation rate, in low-serum medium (1\%), of matched control cells and cells chronically exposed to As(III) $(0.01,0.05,0.1$, and $0.2 \mathrm{mg} / \mathrm{L})$ for 6,10 , and 18 weeks.

It can be seen that the cells treated with As(III) grew more easily in low-serum medium compared with the control cells, even at low concentrations of As in the medium. Cells treated with $0.1 \mathrm{mg} / \mathrm{L}$ of $\mathrm{As}(\mathrm{III})$ for 6 weeks presented a proliferation rate 3.4 times higher 
than the control cells, which was maintained during the remainder of the 24 weeks of treatment. This greater rate of proliferation in serum-depleted medium at As concentrations of 0.05 and $0.2 \mathrm{mg} / \mathrm{L}$ was observed from week 10 .

3.5. Secreted MMP-2 and MMP-9 activity. MMPs are zinc-dependent endopeptidases capable of degrading the extracellular matrix, and are associated with various physiological processes. Dysregulation of their activity is related with various pathologies, including cancer (Kupai et al., 2010; Herszenyi et al., 2012). Furthermore, the study of the secretion of MMPs has been used as a marker of cell transformation induced by inorganic As in other cell types (Sun et al., 2012).

Figure 4 shows the MMP-2 and MMP-9 activity in the conditioned medium of NCM460 cells chronically exposed to As(III) $(0.05$ and $0.1 \mathrm{mg} / \mathrm{L})$ for 24 weeks. The activity of MMP-2 increased in the cells treated with $0.1 \mathrm{mg} / \mathrm{L}$ of As(III) (4.1-fold change) after 24 weeks of exposure. In contrast, the activity of MMP-9 did not change after chronic exposure to As(III).

3.6. Anchorage-independent growth. Figure 5 shows the frequency of formation of colonies greater than $0.2 \mathrm{~mm}$ with respect to untreated cells in soft agar. After 24 weeks of exposure the treatments with 0.05 and $0.1 \mathrm{mg} / \mathrm{L}$ of As(III) produced a higher number of colonies with an anchorage-independent growth (1.7- and 2.2-fold changes, respectively).

3.7. Tumorsphere formation. In order to obtain floating spheres, NCM460 cells chronically exposed to As(III) for 18 and 24 weeks were grown in serum-free medium, in non-adherent conditions (Figure 6). From week 18, chronic treatment with As(III) at a 
concentration of $0.1 \mathrm{mg} / \mathrm{L}$ produced an increase in floating tumorsphere formation in comparison with the control cells (1.9-fold changes, week 18; 2.3-fold changes, week 24). Exposure to $0.05 \mathrm{mg} / \mathrm{L}$ of $\mathrm{As}(\mathrm{III})$ increased the production of tumorspheres after 24 weeks of exposure (1.7-fold changes).

\section{Discussion}

The present study shows that after 24 weeks of treatment with As(III) at concentrations of 0.05 and $0.1 \mathrm{mg} / \mathrm{L}$ non-transformed human epithelial colonic NCM460 cells (Moyer et al., 1996) showed greater ratios of hyperproliferation, anchorage-independent growth, and histone modification, and an increase in MMP-2 activity in comparison with matched control cells. Moreover, the cells treated with As(III) presented a higher secretion of the pro-inflammatory cytokine IL-8 and a down-regulation of $C D X 1$ and $C D X 2$ from the first weeks of exposure, which was maintained throughout the treatment. It should be noted that the control cells show a spontaneous transformation due to their immortalized status, as is the case in most studies of this nature. However, in the presence of the highest concentrations of As (III), the parameters analyzed have much higher values, indicating that chronic exposure to As (III) favors the acquisition of characteristics of transformed cells in intestinal epithelial cells.

Acute inflammation can have a beneficial effect maintaining the cellular homeostasis; however, if inflammation becomes chronic it is an aberrant event. Chronic inflammation has been linked to various stages of tumorigenesis, including cell transformation, tumor progression, endurance, propagation, invasion, angiogenesis and metastasis (Yasmin et al., 2015). Indeed, inflammation is considered a risk factor for development of colorectal cancer (CRC) (Grivennikov et al., 2010). Clinical data showed that patients with stage IV CRC displayed a serum level of IL-8 more than 10 times higher $(1089 \pm 311 \mathrm{pg} / \mathrm{mL})$ than 
in individuals with no evidence of disease $(79 \pm 56 \mathrm{pg} / \mathrm{mL})$ (Ning et al., 2011). It has been demonstrated in vitro that IL8-transfected HCT116 and Caco-2 cells exhibit enhanced xenograft growth and vascularization (Ning et al., 2011). Indeed, antagonism of CXCR2, a receptor of IL-8, with the small molecule SCH 527123 impairs cell proliferation, motility, invasiveness, survival, and sensitivity to oxaliplatin in CRC xenografts (Ning et al., 2012).

The present study also shows an increase in MMP-2 activity in NCM460 cells exposed to $0.1 \mathrm{mg} / \mathrm{L}$ of $\mathrm{As}(\mathrm{III})$ for 24 weeks. These proteins, which are induced in inflammatory processes, can in turn modulate the inflammation by activating, inactivating, or antagonizing the biological functions of cytokines and chemokines (Nissinen and Kähäri, 2014). In recent years it has been shown that MMPs also mediate many of the changes in the microenvironment during tumor progression (Kessenbrock et al., 2010). Expression of various MMPs has been found to be up-regulated in virtually every type of human cancer and correlates with advanced stage, invasive, and metastatic properties (Rundhaug, 2005). Parsons et al. (1998) demonstrated that the ratio of MMP-2 to proMMP-2 was 20-fold higher in colorectal cancer tissue than in non-malignant tissue. Waas et al. (2002) showed that MMP-2 levels, both active and latent forms, in colorectal cancer patients correlated inversely with the stage of the disease; the tumors without synchronous distant metastases containing significantly more active MMP-2 than the others.

Our study also showed that cells treated with As(III) displayed a down-regulation of $C D X 1$ and $C D X 2$ from the $3^{\text {rd }}$ week of treatment. Lower expression of CDX homologues may be related with continuous release of pro-inflammatory cytokines (Coskun et al., 2011). Calon et al. (2007) showed a linkage of $C D X 2$ to inflammation with experimental colitis models. Moreover, Kim et al. (2012) showed that CDX2 expression is repressed 
by the pro-inflammatory cytokine tumor necrosis factor $\alpha$ (TNF- $\alpha$ ). The CDX homologues modulate processes such as proliferation, apoptosis, cell-adhesion, and columnar morphology, promoting the appearance of a mature intestinal cell phenotype (Guo et al., 2004). In addition to these critical roles during development, several studies have described an inverse relationship between $C D X 1$ and $C D X 2$ expression and the extent of dysplasia and severity of CRC, suggesting that altered expression of these genes was associated with colorectal carcinogenesis or tumor progression. Mallo et al. (1998) showed in HT29 cells that both $C D X 1$ and $C D X 2$ genes had to be expressed to reduce tumorigenic potential, to increase sensitivity to apoptosis, and to reduce cell migration. Choi et al. (2006), analyzing the expression pattern of $C D X 2$ protein in relation to the phenotype of 123 sporadic colorectal cancers, observed loss of $C D X 2$ immunostaining in $23.6 \%$ of colorectal adenocarcinomas, and its expression was correlated with the differentiation grade of the carcinoma.

An increase in modified histones was also observed, specifically a greater acetylation of histone $\mathrm{H} 3$ in the intestinal cells treated with As(III) in comparison with the control cells, which appeared after 20 weeks of treatment at the concentrations of 0.05 and 0.1 $\mathrm{mg} / \mathrm{L}$. In cancer cells, disruption of the balance between histone acetyltransferases and deacetylases contributes to transcriptional inactivation of tumor suppressor genes (Jia and Guo, 2013). Zhou et al. (2008) observed significant altered histone modifications induced by very low-dose arsenite $(0.1 \mu \mathrm{M})$ in lung cells, and they suggested that As induces carcinogenesis through the alteration of specific histone methylations. In CRC, aberrant histone modification patterns have been detected, generated by an excess of deregulated enzymes (Gargalionis et al., 2012). Karczmarski et al. (2014) observed a differential abundance of $\mathrm{H} 3 \mathrm{~K} 27 \mathrm{Ac}$ in $\mathrm{CRC}$, a histone post-translational modification associated with 
active enhancers, suggesting a possible role of this modification in regulating genes whose expression changes in CRC.

All these modifications were translated into considerable changes in cell growth, with an increase in proliferation, a greater number of anchorage-independent colonies, and an increase in tumorsphere formation in vitro in cells chronically treated with As(III) in comparison with the control cells.

The results obtained show that non-transformed intestinal epithelium cells may present an increase in the characteristics typical of transformed cells when they are exposed chronically to $\mathrm{As}(\mathrm{III})$ in concentrations similar to those found in drinking water in endemic areas $(0.05-0.1 \mathrm{mg} / \mathrm{L})$. This increase is accompanied by a pro-inflammatory process that begins in the first weeks of exposure and that could be partly responsible for it.

Funding sources. This work was supported by the Spanish Ministry of Economy and Competitiveness (AGL2015-68920-R), for which the authors are deeply indebted. Gabriela de Matuoka e Chiocchetti received a fellowship from the Brazilian Government (CAPES-processo BEX1086/14-6).

\section{References}

Aggarwal, B. B., Shishodia, S., Sandur, S. K., Pandey, M. K., \& Sethi, G. (2006). Inflammation and cancer: how hot is the link? Biochemical Pharmacology, 72, 16051621. doi: 10.1016/j.bcp.2006.06.029

Calatayud, M., Devesa, V., \& Velez, D. (2013). Differential toxicity and gene expression in Caco-2 cells exposed to arsenic species. Toxicology Letters, 218, 70-80. doi: 10.1016/j.toxlet.2013.01.013. 
Calatayud, M., Gimeno-Alcaniz, J.V., Velez, D., \& Devesa, V. (2014). Trivalent arsenic species induce changes in expression and levels of proinflammatory cytokines in intestinal epithelial cells. Toxicology Letters, 224, 40-46. doi: 10.1016/j.toxlet.2013.09.016.

Calon, A., Gross, I., Lhermitte, B., Martin, E., Beck, F., Duclos, B., Kedinger, M., Duluc, I., Domon-Dell, C., \& Freund, J.-N. (2007). Different effects of the CDX1 and CDX2 homeobox genes in a murine model of intestinal inflammation. Gut, 56, 1688-1695. doi: 10.1136/gut.2007.125542.

Chen, C.-J., Chuang, Y.-C., Lin, T.-M., \& Wu, H.-Y. (1985). Malignant neoplasms among residents of a blackfoot disease-endemic area in Taiwan: high-arsenic artesian well water and cancers. Cancer Research, 45, 5895-5899.

Chen, Q. Y., \& Costa, M. (2017). A comprehensive review of metal-induced cellular transformation studies. Toxicology and Applied Pharmacology, 331, 33-40. doi: 10.1016/j.taap.2017.05.004.

Chiocchetti, G. M., Vélez, D., \& Devesa, V. (2018). Effect of subchronic exposure to inorganic arsenic on the structure and function of the intestinal epithelium. Toxicology Letters, 206, 80-88. doi: 10.1016/j.toxlet.2018.01.011.

Choi, B. J., Kim, C. J., Cho, Y. G., Song, J. H., Kim, S. Y., Nam, S. W., Lee, S. H., Yoo, N. J., Lee, J. Y., \& Park, W. S. (2006). Altered expression of CDX2 in colorectal cancers. Apmis, 114, 50-54. doi: 10.1111/j.1600-0463.2006.apm_292.x.

Coskun, M., Troelsen, J. T., \& Nielsen, O. H. (2011). The role of CDX2 in intestinal homeostasis and inflammation. Biochimica et Biophysica Acta-Molecular Basis of Disease, 1812, 283-289. doi: 10.1016/j.bbadis.2010.11.008.

Gargalionis, A.N., Piperi, C., Adamopoulos, C., \& Papavassiliou, A.G. (2012). Histone modifications as a pathogenic mechanism of colorectal tumorigenesis. International Journal of Biochemistry \& Cell Biology, 44, 1276-1289. doi: 10.1016/j.biocel.2012.05.002.

Grivennikov, S. I., Greten, F. R., \& Karin, M. (2010). Immunity, inflammation, and cancer. Cell, 140, 883-899. doi: 10.1016/j.cell.2010.01.025.

Guo, R.-J., Suh, E. R., \& Lynch, J. P. (2004). The role of Cdx proteins in intestinal development and cancer. Cancer Biology \& Therapy, 3, 593-601. doi: 10.4161/cbt.3.7.913. 
Herszenyi, L., Hritz, I., Lakatos, G., Varga, M. Z., \& Tulassay, Z. (2012). The behavior of matrix metalloproteinases and their inhibitors in colorectal cancer. International Journal of Molecular Sciences, 13, 13240-13263. doi: 10.3390/ijms131013240.

IARC, 2004. Monographs on the Evaluation of Carcinogenic Risks to Humans. Overall Evaluations of Carcinogenicity: an Updating of IARC Monographs. International Agency for Cancer Research 84, 39.

Jia, Y., \& Guo, M. (2013). Epigenetic changes in colorectal cancer. Chinese Journal of Cancer, 32, 21-30. doi: 10.5732/cjc.011.10245.

Johnson, S., Chen, H., \& Lo, P (2013). In vitro tumorsphere formation assays. BioProtocol, 3, e325. doi: 10.21769/BioProtoc.325.

Karczmarski, J., Rubel, T., Paziewska, A., Mikula, M., Bujko, M., Kober, P., Dadlez, M., \& Ostrowski, J. (2014). Histone H3 lysine 27 acetylation is altered in colon cancer. Clinical Proteomics, 11, 24. doi: 10.1186/1559-0275-11-24.

Kessenbrock, K., Plaks, V., \& Werb, Z. (2010). Matrix metalloproteinases: regulators of the tumor microenvironment. Cell, 141, 52-67. doi: 10.1016/j.cell.2010.03.015.

Kim, J. J., Shajib, M. S., Manocha, M. M., \& Khan, W. I. (2012). Investigating intestinal inflammation in DSS-induced model of IBD. Journal of Visualized Experiments, 60, e3678. doi: 10.3791/3678.

Kupai, K., Szucs, G., Cseh, S., Hajdu, I., Csonka, C., Csont, T., \& Ferdinandy, P. (2010). Matrix metalloproteinase activity assays: Importance of zymography. Journal of Pharmacological and Toxicological Methods, 61, 205-209. doi: 10.1016/j.vascn.2010.02.011.

Lee, C.-H., Liao, W.-T., \& Yu, H.-S. (2010). Mechanisms and immune dysregulation in arsenic skin carcinogenesis. Journal of Cancer Therapy, 1, 76. doi: 10.4236/jct.2010.12013.

Mallo, G. V., Soubeyran, P., Lissitzky, J.-C., André, F., Farnarier, C., Marvaldi, J., Dagorn, J.-C., \& Iovanna, J. L. (1998). Expression of the Cdx 1 and Cdx2 homeotic genes leads to reduced malignancy in colon cancer-derived cells. Journal of Biological Chemistry, 273, 14030-14036. doi: 10.1074/jbc.273.22.14030.

Moyer, M. P., Manzano, L. A., Merriman, R. L., Stauffer, J. S., \& Tanzer, L. R. (1996). NCM460, a normal human colon mucosal epithelial cell line. In Vitro Cellular \& Developmental Biology, 32, 315-317. doi:10.1007/BF02722955.

Ning, Y., Manegold, P .C., Hong, Y. K., Zhang, W., Pohl, A., Lurje, G., Winder, T., Yang, D., LaBonte, M. J., \& Wilson, P. M. (2011). Interleukin-8 is associated with 
proliferation, migration, angiogenesis and chemosensitivity in vitro and in vivo in colon cancer cell line models. International Journal of Cancer, 128, 2038-2049. doi: 10.1002/ijc.25562.

Ning, Y., Labonte, M. J., Zhang, W., Bohanes, P. O., Gerger, A., Yang, D., Benhaim, L., Paez, D., Rosenberg, D. O., \& Venkata, K. C. N. (2012). The CXCR2 antagonist, SCH-527123, shows antitumor activity and sensitizes cells to oxaliplatin in preclinical colon cancer models. Molecular Cancer Therapeutics, 11, 1353-1364. doi: 10.1158/1535-7163.MCT-11-0915.

Nissinen, L., \& Kähäri, V.-M. (2014). Matrix metalloproteinases in inflammation. Biochimica et Biophysica Acta - General Subjects, 1840, 2571-2580. doi: 10.1016/j.bbagen.2014.03.007.

Parsons, S., Watson, S., Collins, H., Griffin, N., Clarke, P., \& Steele, R. (1998). Gelatinase (MMP-2 and -9) expression in gastrointestinal malignancy. British Journal of. Cancer, 78, 1495. doi: 10.1038/bjc.1998.712.

Ren, F., Sheng, W.-Q., \& Du, X. (2013). CD133: a cancer stem cells marker, is used in colorectal cancers. World Journal of Gastroenterology, 19, 2603. doi: 10.3748/wjg.v19.i17.2603.

Ricci-Vitiani, L., Lombardi, D. G., Pilozzi, E., Biffoni, M., Todaro, M., Peschle, C., \& De Maria, R. (2007). Identification and expansion of human colon-cancer-initiating cells. Nature, 445, 111. doi: 10.1038/nature05384.

Rossman, T. G. (2003). Mechanism of arsenic carcinogenesis: an integrated approach. Mutation Research, 533, 37-65. doi: 10.1016/j.mrfmmm.2003.07.009.

Roy, R. V., Son, Y.-O., Pratheeshkumar, P., Wang, L., Hitron, J. A., Divya, S. P., Rakesh, D., Kim, D., Yin, Y., \& Zhang, Z. (2015). Epigenetic targets of arsenic: emphasis on epigenetic modifications during carcinogenesis. Journal of Environmental Pathology, Toxicology, and Oncology, 34, 63-84. doi: 10.1615/JEnvironPatholToxicolOncol.2014012066.

Rubin, D. C., Shaker, A., \& Levin, M. S. (2012). Chronic intestinal inflammation: inflammatory bowel disease and colitis-associated colon cancer. Frontiers in Immunology, 3, 107. doi: 10.3389/fimmu.2012.00107.

Rundhaug, J. E. (2005). Matrix metalloproteinases and angiogenesis. Journal of Cellular and Molecular Medicine, 9, 267-285. doi: 10.1111/j.1582-4934.2005.tb00355.x.

Shechter, D., Dormann, H. L., Allis, C. D., \& Hake, S. B. (2007). Extraction, purification and analysis of histones. Nature Protocols, 2, 1445. doi: 10.1038/nprot.2007.202. 
Sun, Y., Tokar, E. J., \& Waalkes, M. P. (2012). Overabundance of putative cancer stem cells in human skin keratinocyte cells malignantly transformed by arsenic. Toxicological Sciences, 125, 20-29. doi: 10.1093/toxsci/kfr282.

Waas, E., Lomme, R., DeGroot, J., Wobbes, T., \& Hendriks, T. (2002). Tissue levels of active matrix metalloproteinase-2 and -9 in colorectal cancer. British Journal of Cancer, 86, 1876. doi: 10.1038/sj.bjc.6600366.

Werling, R. W., Yaziji, H., Bacchi, C. E., \& Gown, A. M. (2003). CDX2, a highly sensitive and specific marker of adenocarcinomas of intestinal origin: an immunohistochemical survey of 476 primary and metastatic carcinomas. American Journal of Surgical Pathology, 27, 303-310. doi: 10.1097/00000478-20030300000003

WHO, World Health Organization, (2012). Arsenic. Fact sheet no. 372. htpp://www.who.int/mediacentre/factsheets/fs372/en/ (accessed 4 September 2017).

Wong, N., Britton, M., Choi, G., Stanton, T., Bicknell, D., Wilding, J., \& Bodmer, W. (2004). Loss of CDX1 expression in colorectal carcinoma: promoter methylation, mutation, and loss of heterozygosity analyses of 37 cell lines. Proceedings of the National Academy of Sciences of the United States of America, 101, 574-579. doi: 10.1073/pnas.0307190101.

Yasmin, R., Siraj, S., Hassan, A., Khan, A. R., Abbasi, R., \& Ahmad, N. (2015). Epigenetic regulation of inflammatory cytokines and associated genes in human malignancies. Mediators of Inflammation, 2015, ID 201703. doi: $10.1155 / 2015 / 201703$.

Zhou, X., Sun, H., Ellen, T. P., Chen, H., \& Costa, M. (2008). Arsenite alters global histone H3 methylation. Carcinogenesis, 29, 1831-1836. doi: 10.1093/carcin/bgn063. 


\section{Figure legends}

Figure 1. Release of the pro-inflammatory cytokine IL-8 to the culture medium in control cells and cells chronically exposed to $\operatorname{As}(\mathrm{III})(0.01,0.05,0.1$, and $0.2 \mathrm{mg} / \mathrm{L})$ for 4,14 , and 24 weeks. Values expressed as $\mathrm{pg} / 10^{6}$ cells (mean $\left.\pm \mathrm{SD}, \mathrm{n}=4\right)$. Asterisks indicate statistically significant differences $(p<0.05)$ with respect to the matched control cells.

Figure 2. Histone modification in cells chronically exposed to As(III) (0.01, 0.05, 0.1, and $0.2 \mathrm{mg} / \mathrm{L})$ for 6,18 , and 20 weeks. Values expressed as mean $\pm \operatorname{SD}(\mathrm{n}=2)$. Treated cells data were compared with data from matched control cells. Asterisks indicate statistically significant differences $(p<0.05)$ with respect to the control cells.

Figure 3. Cell proliferation of control cells and cells chronically exposed to As(III) (0.05, $0.01,0.1$, and $0.2 \mathrm{mg} / \mathrm{L}$ ) for 6,10 , and 18 weeks, grown in serum-reduced medium. Values expressed as total number of cells $\left(\times 10^{5}\right)($ mean $\pm \mathrm{SD}, \mathrm{n}=4)$. Asterisks indicate statistically significant differences $(p \leq 0.05)$ with respect to the matched control cells.

Figure 4. MPP-2 and MMP-9 activity in conditioned medium in cells chronically exposed to As(III) (0.05 and $0.1 \mathrm{mg} / \mathrm{L})$ for 24 weeks. Values expressed as mean $\pm \mathrm{SD}(\mathrm{n}$ $=2)$. Treated cells data were compared with data from matched control cells. Asterisks indicate statistically significant differences $(p<0.05)$ with respect to the control cells.

Figure 5. Colony formation in cells chronically exposed to As(III) $(0.01,0.05,0.1$, and $0.2 \mathrm{mg} / \mathrm{L})$ for 24 weeks. Values expressed as mean $\pm \operatorname{SD}(n=4)$. Treated cells data were compared with data from matched control cells. Asterisks indicate statistically significant differences $(p<0.05)$ with respect to the matched control cells.

Figure 6. Tumorsphere formation in cells chronically exposed to As(III) (0.05 and 0.1 $\mathrm{mg} / \mathrm{L})$ for 18 and 24 weeks. Values expressed as mean $\pm \mathrm{SD}(\mathrm{n}=4)$. Treated cells data were compared with data from matched control cells. Asterisks indicate statistically significant differences $(p<0.05)$ with respect to the matched control cells. 


\begin{tabular}{ccccc}
\hline Gene & GenBank ID & Sequence 5'-3' & $\begin{array}{c}\text { Amplicon size } \\
\text { (bp) }\end{array}$ & Efficiency \\
\hline CDX1 & NM_001804.2 & $\begin{array}{l}\text { F: CACAATCCGGCCGAAATC } \\
\text { R:TCACTTTGCGCTCCTTTGC }\end{array}$ & 101 & $2.08 \pm 0.07$ \\
CDX2 & NM_001265.4 & $\begin{array}{l}\text { F: GCTGGAGAAGGAGTTTCACTACAGT } \\
\text { R: TAACCAGATTTTAACCTGCCTCTCA }\end{array}$ & 103 & $2.11 \pm 0.19$ \\
CD133 & NM_006017.2 & $\begin{array}{l}\text { F: TTGGCTCAGACTGGTAAATCCC } \\
\text { R: ATAGGAAGGACTCGTTGCTGGT }\end{array}$ & 161 & $2.10 \pm 0.19$ \\
RN18S & NR_003286.2 & $\begin{array}{l}\text { F: CCATCCAATCGGTAGTAGCG } \\
\text { R: GTAACCCGTTGAACCCCATT }\end{array}$ & 151 & $2.00 \pm 0.01$ \\
\hline
\end{tabular}

Table 1. Sequence and efficiency of the oligonucleotides used in the study 


\begin{tabular}{|c|c|c|c|c|c|c|c|c|c|}
\hline & \multicolumn{3}{|c|}{ Week 3} & \multicolumn{3}{|c|}{ Week 13} & \multicolumn{3}{|c|}{ Week 19} \\
\hline & $C D X 1$ & $C D X 2$ & $C D 133$ & $C D X 1$ & $C D X 2$ & $C D 133$ & $C D X 1$ & $C D X 2$ & CD133 \\
\hline $0.01 \mathrm{mg} / \mathrm{L}$ & $-2.21 \pm 0.03^{*}$ & $-1.86 \pm 0.04^{*}$ & $-1.43 \pm 0.01 *$ & $-2.00 \pm 0.05^{*}$ & $-0.94 \pm 0.05$ & $2.63 \pm 0.88^{*}$ & $-2.19 \pm 0.03 *$ & $-1.95 \pm 0.04 *$ & $0.32 \pm 0.12$ \\
\hline $0.05 \mathrm{mg} / \mathrm{L}$ & $1.61 \pm 0.75$ & $3.97 \pm 1.5^{*}$ & $1.52 \pm 0.57$ & $-4.49 \pm 0.01^{*}$ & $-3.46 \pm 0.02 *$ & $3.90 \pm 1.90^{*}$ & $-4.86 \pm 0.01 *$ & $-4.50 \pm 0.02 *$ & $0.66 \pm 0.15$ \\
\hline $0.1 \mathrm{mg} / \mathrm{L}$ & $-5.95 \pm 0.01 *$ & $-3.36 \pm 0.02 *$ & $0.20 \pm 0.07$ & $-6.00 \pm 0.004 *$ & $-6.34 \pm 0.003 *$ & $3.56 \pm 1.35^{*}$ & $-5.43 \pm 0.01^{*}$ & $-5.29 \pm 0.01^{*}$ & $0.51 \pm 0.17$ \\
\hline $0.2 \mathrm{mg} / \mathrm{L}$ & $-6.69 \pm 0.002 *$ & $-4.15 \pm 0.02 *$ & $0.38 \pm 0.08$ & $-6.40 \pm 0.003 *$ & $-8.20 \pm 0.001 *$ & $3.77 \pm 1.57$ & $-5.69 \pm 0.004 *$ & $-7.73 \pm 0.004 *$ & $0.03 \pm 0.01$ \\
\hline
\end{tabular}

Table 2. Relative expression of $C D X 1, C D X 2$, and $C D 133$ in NCM460 cells chronically exposed to As(III) (0.01, 0.05, 0.1, and 0.2 mg/L) for 3 , 13, and 19 weeks with respect to the matched control cells. Values expressed as log base 2 (mean \pm standard deviation, $n=4)$. An asterisk indicates statistically significant down-regulation (red) or up-regulation (blue) with respect to control cells $(\mathrm{p}<0.05)$. 
Figure 1.

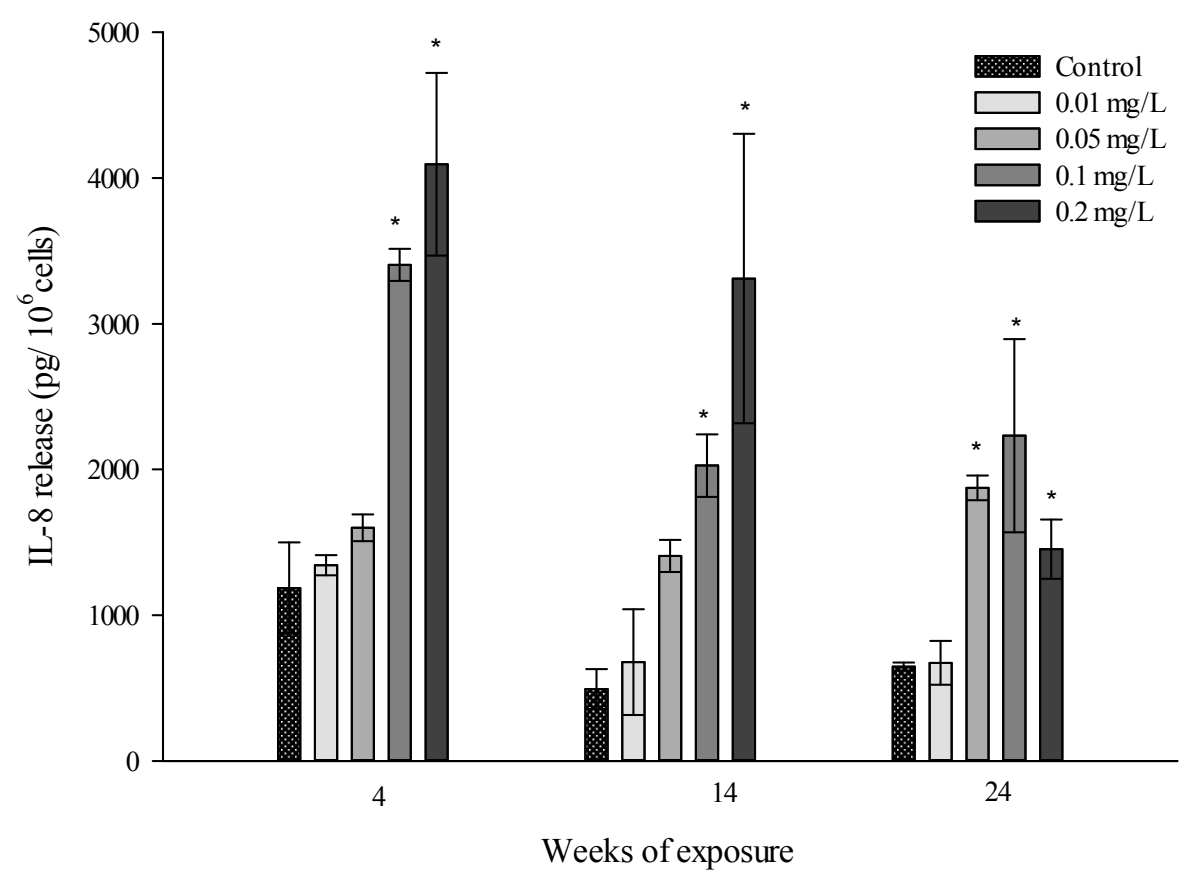


Figure 2.

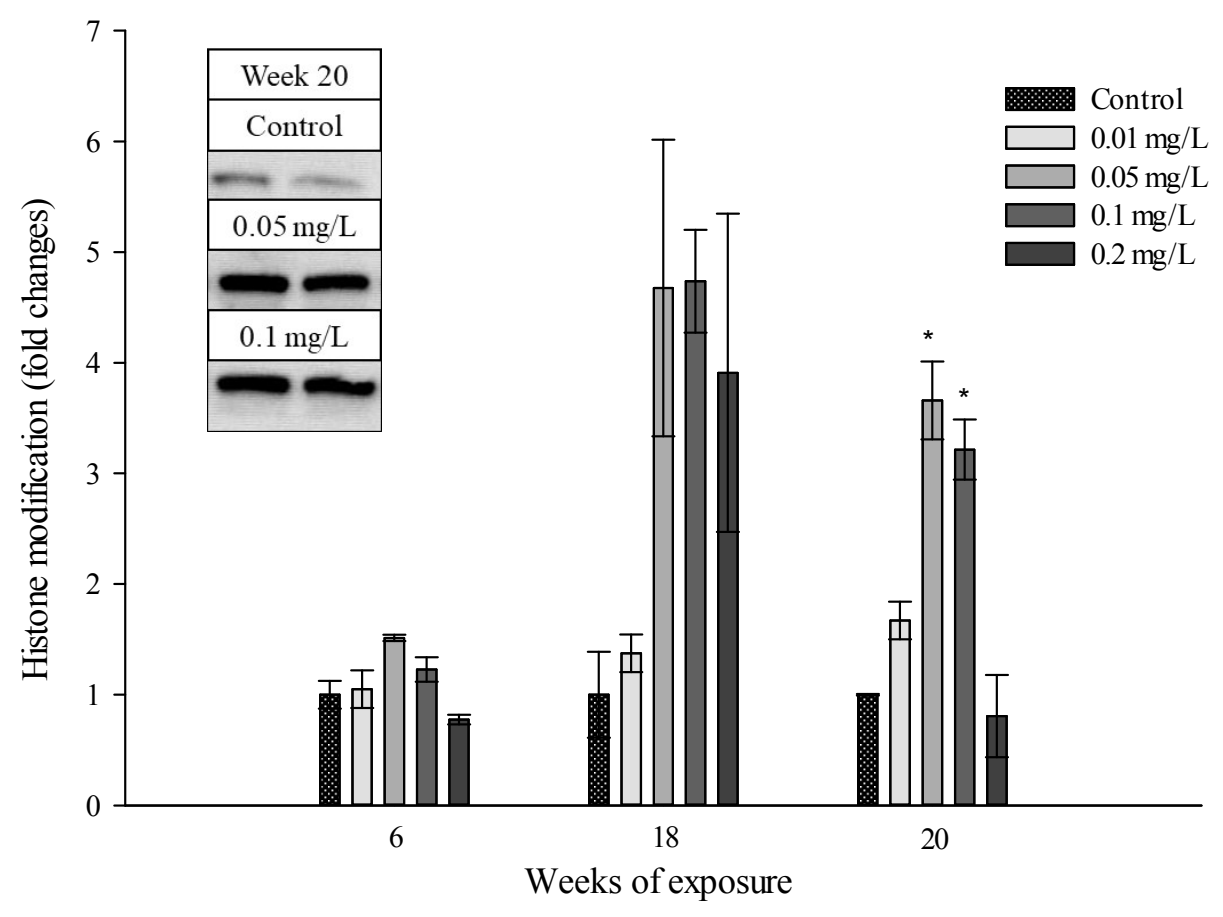


Figure 3.

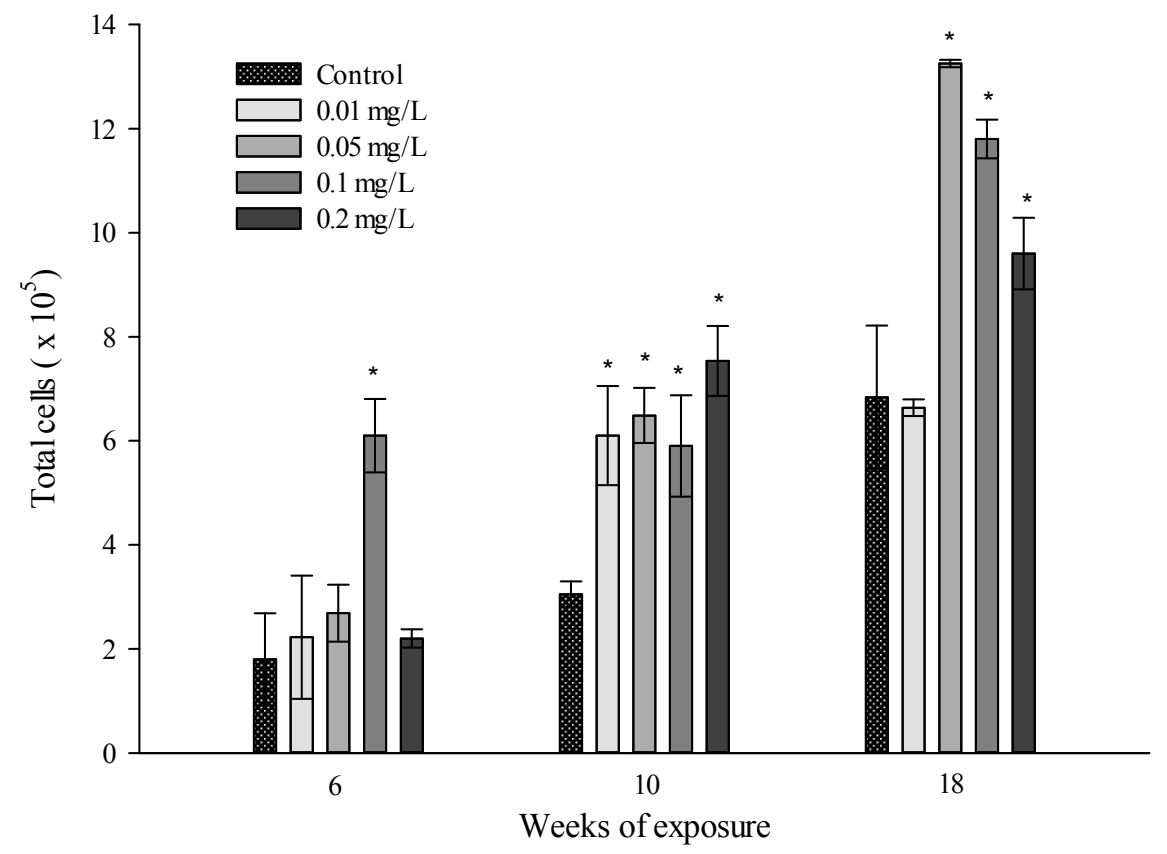


Figure 4.

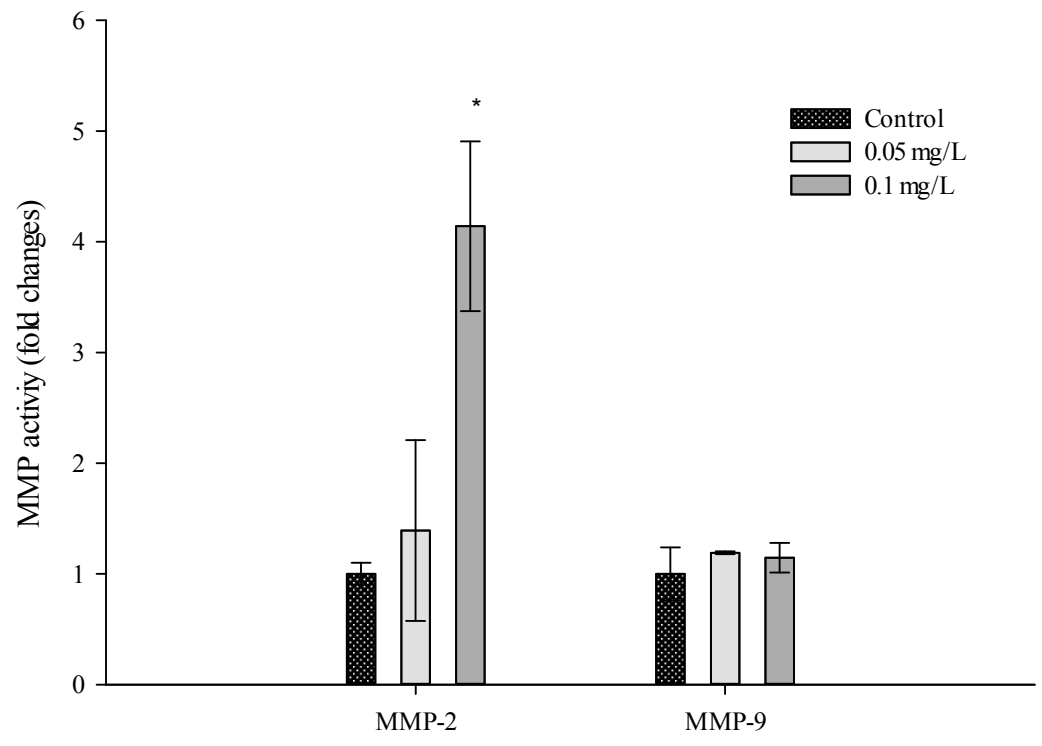


Figure 5.
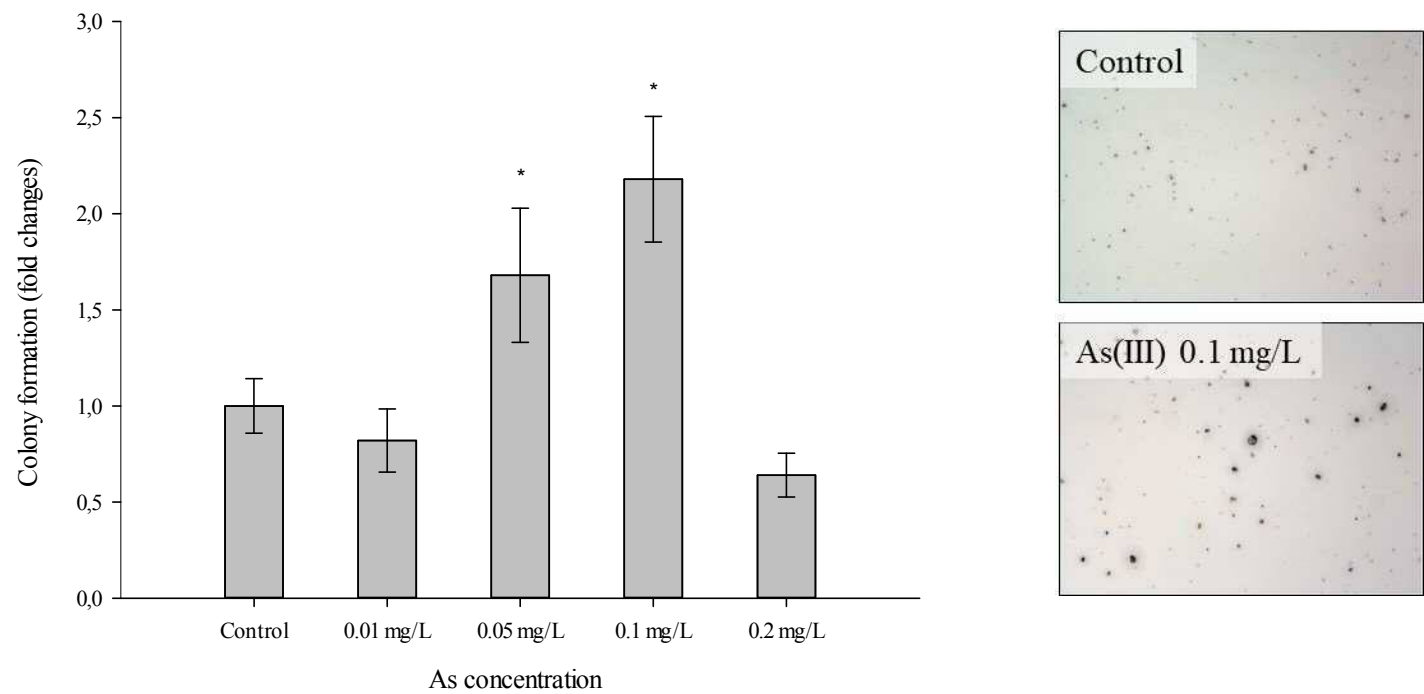
Figure 6.

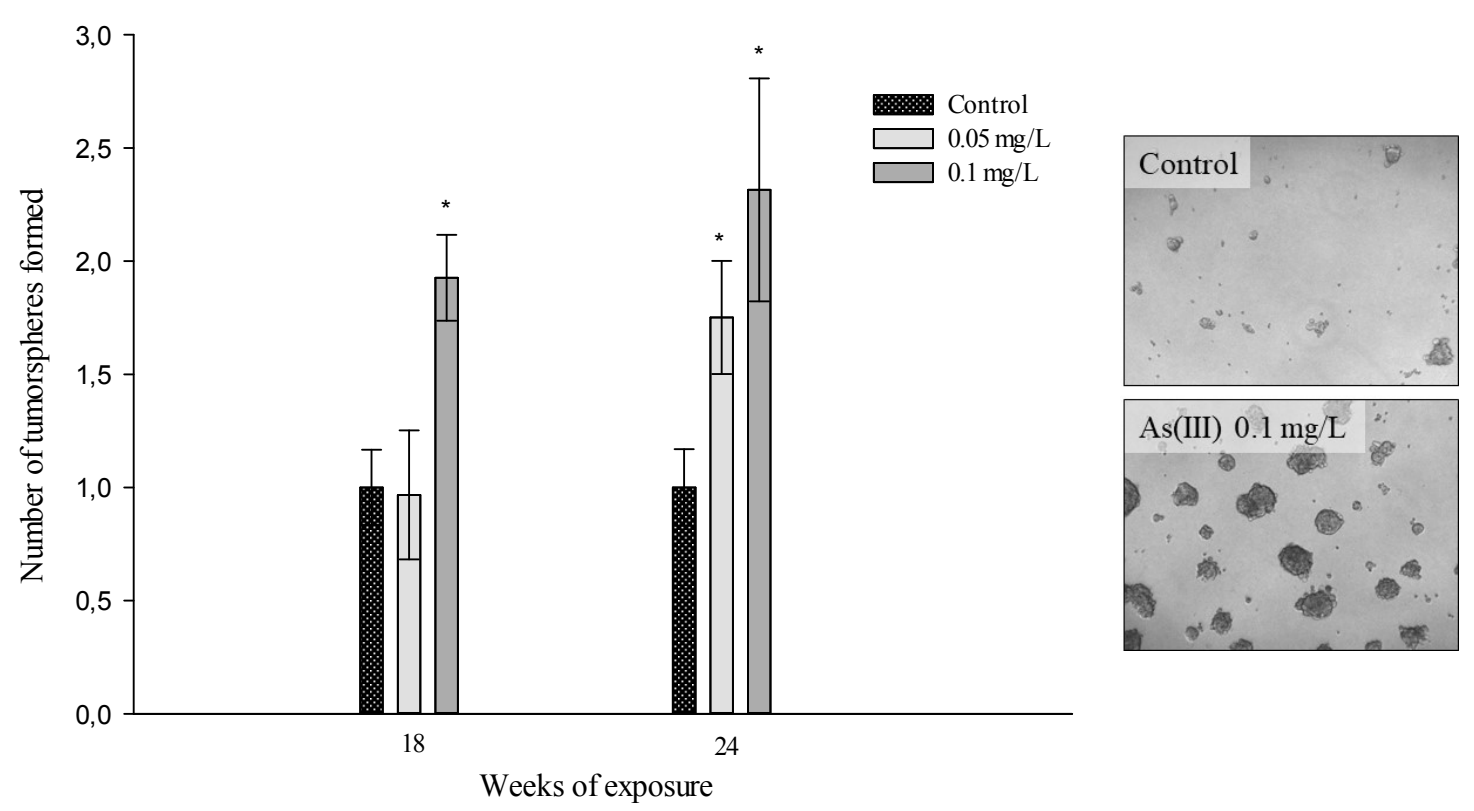

